\title{
USE OF COST MANAGEMENT IN REAL ESTATE MARKET IN THE CZECH REPUBLIC
}

\author{
Jakub Holcman ${ }^{1}$, Jiří Kozel ${ }^{2}$ \\ ${ }^{1}$ Czech Technical University, Faculty of Civil Engineering, Thákurova 7, Prague 6, 166 29, Czech \\ Republic, jakub.holcman@fsv.cvut.cz \\ ${ }^{2}$ Swietelsky stavební s.r.o., Sokolovská 192/79, Prague 8, 186 00, Czech Republic, j.kozel@swietelsky.cz
}

\begin{abstract}
This work deals with the application of cost management processes in the selection of real estate intended for housing. The paper focuses specifically on apartments in the Czech Republic, Prague. The selection of real estate is considered as a project, since this activity has all possible aspects of project management. A frequent mistake in choosing is to assess only the bid price in relation to the conditions and the location. Here the costs of real estate operation are solved, without the liquidation phase. However, future costs associated with the operation of the property always differ. This paper presents all possible costs associated with the use of a housing unit. Cost management procedures are planning, cost estimation, budgeting and cost control. By adapting the cost management rules to buy an apartment, the risk of inappropriate trade is reduced for most consumer units. It is possible to avoid unreasonable purchases and distortions of the real estate market not only in the Czech Republic but also in other locations. The aim of the work is to present costs that the buyer must calculate when choosing a suitable property and how to subsequently manage or control it.
\end{abstract}

\section{Keywords}

Analysis, apartment, cost management, project

\section{JEL Classification}

M21 Business Economics

R31 Housing Supply and Markets

DOI: https://doi.org/10.14311/bit.2020.02.03

Editorial information: journal Business \& IT, ISSN 2570-7434, CreativeCommons license (c) (i) published by CTU in Prague, 2020, http://bit.fsv.cvut.cz/ 


\section{Introduction}

Research on price-setting factors in the residential market is currently underway. Part of this research is also the application of project management rules to the behavior of entities in the real estate market. In the real estate market, it is possible to manage real estate business, offer of available real estate for sale or lease, as well as individual real estate portfolios that are dealt with within facility management. Real estate prices are dependent on many microeconomic and macroeconomic factors. In the real estate market, quality and well-founded decisions are important [1], which corresponds to project management rules. Factors affecting house prices in individual regions are not the same [2], [3]. Generally, the most debatable factors in professional articles are location, civic amenities, transport accessibility, job offer, mortgage interest rates, etc. All these factories mainly determine the purchase price of the property.

Pricing factors also affect the operating costs that the property owner must be able to meet. Typologically, operating costs will not change, or slightly, in different regions (countries), depending on legislation. Certainly, these costs will change, as there are different price levels and living conditions globally. This article deals primarily with the identification of the basic typology of operating costs related to the personal ownership of residential real estate in the capital of the Czech Republic, Prague. By means of cost management rules a clear and clear procedure how to assess real estate is presented. This is an important aspect when assessing the availability of housing. The availability of housing cannot be assessed solely based on the ability to obtain a mortgage loan from a bank or other financial institution.

\section{Methodology}

The basics of project management, as outlined in A guide to project management body of knowledge, include a description of how cost management works [4]. Cost management includes planning processes, cost estimation, budgeting and control. Different entities in the real estate market measure the cost of real estate in a different way and at a different time. The buyer has to count on the highest number of different costs, as opposed to the seller or sales agent. In general, the following procedure applies to cost management [4]:

Table 1: Cost management processes

\begin{tabular}{|l|l|}
\hline Process according to [4] & Purpose in real estate market \\
\hline Plan cost & $\begin{array}{l}\text { Creates plan how to work with costs in future time. Gives list of } \\
\text { important and considered costs. }\end{array}$ \\
\hline Estimate costs & $\begin{array}{l}\text { Estimates the amount of costs required for whole life cycle of property } \\
\text { in private ownership and related expenses. }\end{array}$ \\
\hline Determine budget & $\begin{array}{l}\text { Provides a definitive overview of the composition and amount of costs } \\
\text { that should not be exceeded in order to keep the property available. } \\
\text { Based on this budget, actual expenditures and plans are checked in the } \\
\text { future }\end{array}$ \\
\hline Control costs & $\begin{array}{l}\text { Owner must control planned costs with income of household. It } \\
\text { contains checking of new agreements for energy supply, repairs or } \\
\text { taxes. }\end{array}$ \\
\hline
\end{tabular}

Tools for individual processes are according to [4] e.g.: expert judgment, parametric estimating, bottom-up estimating, three-point estimating, reserve analysis, project management software, cost of quality, vendor bid analysis, historical relationships, funding limit reconciliation, performance reviews, etc. 
In most cases, the estimate costs and determine budget processes are merged into one process where smaller projects are determined using simple methods - calculation, unit prices of suppliers, etc. [4]. Planning and cost control are very important processes, because without these processes it would be a totally reckless purchase of real estate. Before buying a residential property, analyzes and calculations are an essential element in determining affordability for the buyer. For many buyers, investing in a privately-owned residential property is often the only and highest investment in life. After purchasing the property, its operation may become liquidation for the buyer. In the construction industry, cost management processes are a continuous activity - especially from the perspective of general contractors. The continuity of procurement, construction and completion requires the approach of entire economic departments. For real estate business, the initial balance sheet is primarily needed, so the time required is not continuous but one-off. For initial cost analysis and plan creation, it is advisable to use real estate agencies or expert advice. In the case of this work, it is an initial identification of all the costs to be considered when planning the acquisition of own housing.

The costs were determined by analyzing the offer advertisements on the most used real estate website in the Czech Republic Sreality.cz [5]. Currently (April 2020) there are 3952 privately owned flats for sale in Prague [5]. These are apartments with one to five living rooms plus kitchen, bathroom and toilet. The price range is from EUR 59,000 EUR to 1.8 million EUR. A total of 270 apartments for sale do not have a bid price. There are 662 family houses in the capital [5]. The price range is from 89,000 EUR - 2.8 million EUR, while out of a total of 662 for 130 advertisements, the price of the property is only on request and showing interest at the real estate agency. The properties for which the price is not listed usually have the character of luxury apartments and houses, or occur in very preferred locations (city center, historic center, historical building, houses with large land plots, etc.).
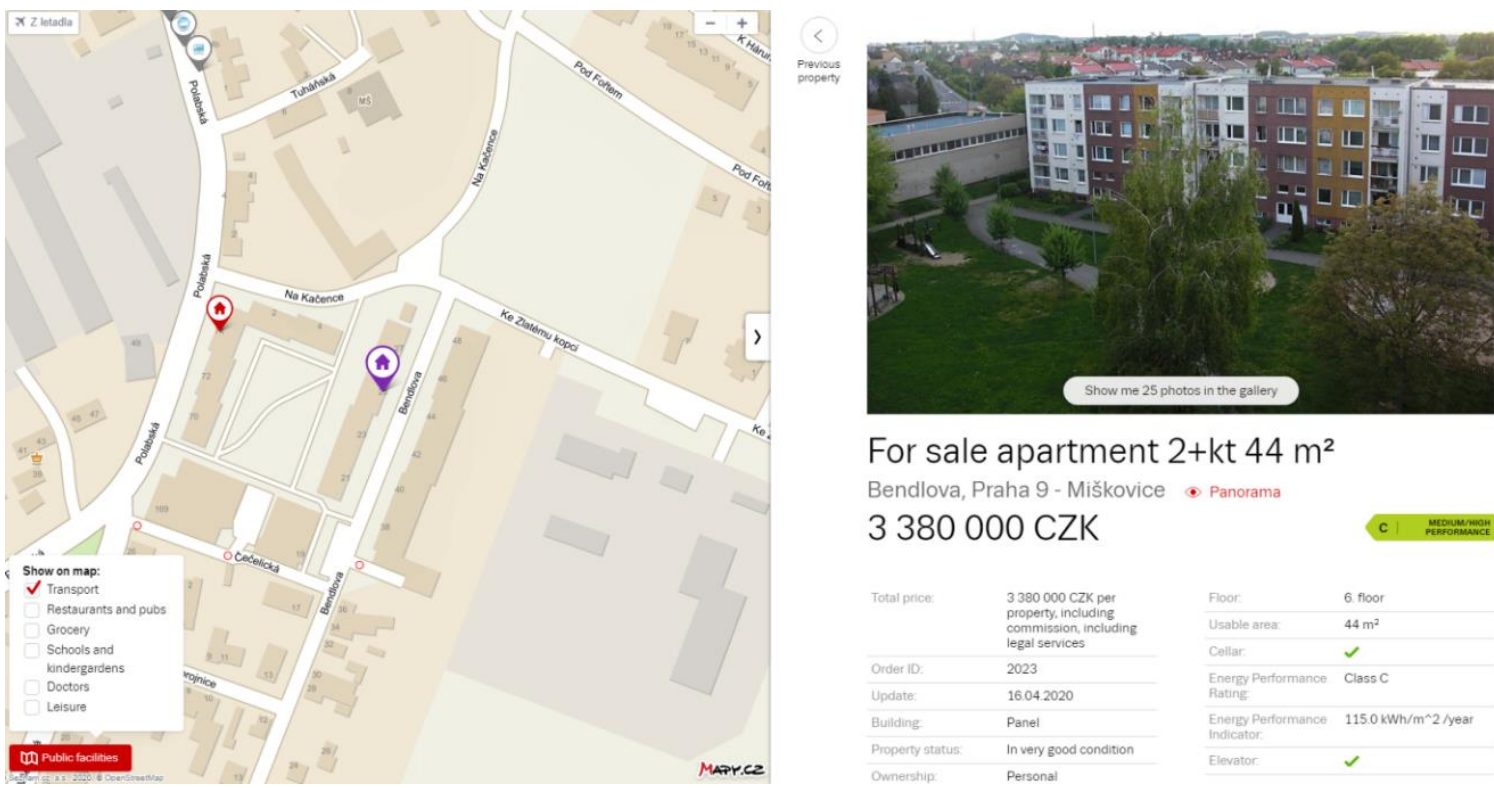

For sale apartment 2+kt $44 \mathrm{~m}^{2}$ Bendlova, Praha 9 - Miškovice - Panorama 3380000 CZK

Figure 1: Example of bid advertisement and available information (source: [6])

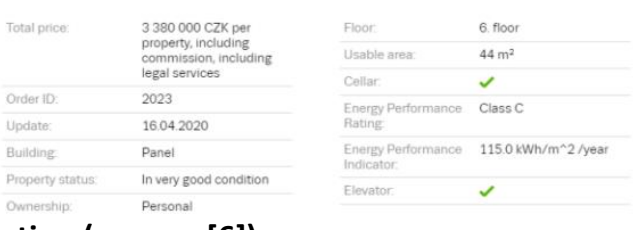

At the Faculty of Civil Engineering, Department of Economics and Management in Civil Engineering, software for obtaining data from this real estate website is being developed. However, these data do not provide detailed information on all costs that may be associated with the property. For this reason, each advertisement was examined separately, since only in this way could it be possible to obtain information on the type of costs. The location of the property was monitored due to the civic amenities on the map, which is always part of the advertisement. It has been also looked at photos taken by the owners or real estate agents to find possible information on maintenance, technical condition of the property, parking options, etc. It is therefore a manual and time-consuming work, 
which, however, yields unique knowledge that could not be recognized in the table. Important is also the text of the advertisement, which in several cases points out the conditions and other costs that must be paid in case of purchase. The most common case is the condition of buying a cellar and a parking space for the apartment to be sold. It is therefore not possible to buy an apartment without these premises, even if the buyer does not have a car. These are additional high amounts of acquisition costs that may be decisive for obtaining a mortgage loan if the buyer does not have enough equity. The availability of equity for the acquisition of own housing in the Czech Republic is a major problem. The buyer must have at least $10-20 \%$ of the purchase price (depending on the type of property) $+4 \%$ to pay real estate acquisition tax. Ascertained costs fully associated with real estate are recorded in the following chapter, Table 2 Typology of operated and related costs.

\section{Analysis results}

Just as society evolves, so does housing. The growth of smart homes and the incorporation of modern technologies have an impact on new types of costs. The costs identified by the analysis should give a comprehensive overview not only to experts, but also directly to the buyer, what to count on the acquisition of real estate. What costs to include in their plans (First process of cost management), which to evaluate and compare with household income (Second and third process of cost management), and which to control (Fourth process of cost management) for sustainability availability of own housing. If any of these steps is wrong, then there is a risk of distrain, loss of property, moving to a smaller property, lack of confidence to repay obligations, etc.

Table 2: Typology of operated and related costs. (Source: Authors judgement)

\begin{tabular}{|l|l|l|}
\hline \multicolumn{1}{|c|}{ Costs } & \multicolumn{1}{|c|}{ Description } & \multicolumn{1}{|c|}{ Frequency } \\
\hline Initial costs & $\begin{array}{l}\text { Depends on type of property - bid price / } \\
\text { purchase price. There is included VAT only for } \\
\text { new property. }\end{array}$ & Once \\
\hline Parking slot and cellar room & $\begin{array}{l}\text { For new property necessary part of the } \\
\text { purchase }\end{array}$ & Once \\
\hline Real estate acquisition tax & $\begin{array}{l}4 \% \text { in the Czech Republic - only for older } \\
\text { property. This tax should be abolished (in } \\
\text { negotiations) }\end{array}$ & Once \\
\hline Real estate tax & According to formula of Ministry of Finance & Yearly \\
\hline Deposit in the Cadastral office & To change owner & Once \\
\hline Provision to real estate agency & Advertising, buyer search & $\begin{array}{l}\text { Once } \\
\text { to need According }\end{array}$ \\
\hline $\begin{array}{l}\text { Legal service } \\
\text { Mortgage negotiation fee }\end{array}$ & $\begin{array}{l}\text { Fee at the beginning of the agreement with } \\
\text { the bank }\end{array}$ & Once \\
\hline $\begin{array}{l}\text { Interest on the loan } \\
\text { (mortgage) plus fees }\end{array}$ & Average interest rate 2,42 \% [7] & Monthly \\
\hline $\begin{array}{l}\text { Reconstruction, } \\
\text { modernization }\end{array}$ & When buying older property & According to need \\
\hline $\begin{array}{l}\text { Minor repairs } \\
\text { Major repairs }\end{array}$ & $\begin{array}{l}\text { During using - each 3 to 5 years (painting, } \\
\text { plumbing, etc.) }\end{array}$ & $\begin{array}{l}\text { Once per 3 to } 5 \\
\text { years }\end{array}$ \\
\hline $\begin{array}{l}\text { (tiling replacement, fixtures, heating, etc.) } \\
\text { Repair loan (commung }\end{array}$ & High loan for essential modernization & Once per 10 years \\
\hline
\end{tabular}




\begin{tabular}{|c|c|c|}
\hline Repairs fund & $\begin{array}{l}\text { Smaller amount of money for basic repairs in } \\
\text { common areas }\end{array}$ & Monthly \\
\hline Service of equipment & $\begin{array}{l}\text { Revision of chimney, gas boiler, lightning } \\
\text { conductor, etc. }\end{array}$ & $\begin{array}{l}\text { Once per } 2 \text { to } 3 \\
\text { years }\end{array}$ \\
\hline Insurance & $\begin{array}{ll}\text { Real estate insurance Plus } & \text { liability } \\
\text { insurance (water accident) } & \\
\end{array}$ & Yearly \\
\hline Furnishings & $\begin{array}{l}\text { According to the size of the new property, } \\
\text { client requirements. New kitchen with } \\
\text { equipment }\end{array}$ & Once \\
\hline Electricity & Payments to the supplier & Monthly \\
\hline Gas & Payments to the supplier & Quarterly \\
\hline Water (include sewerage) & Payments to the supplier & Monthly \\
\hline Heating & $\begin{array}{l}\text { The height of ceiling is important for the sum } \\
\text { of heat consumption }\end{array}$ & Monthly \\
\hline Energy label of the building & $\begin{array}{l}\text { Planned energy consumption (insulation, } \\
\text { new windows, roof, heating system, energy } \\
\text { recovery-photovoltaics, heat pumps, etc.) }\end{array}$ & According to need \\
\hline Facility management & Joint payments in the community of owners & Monthly \\
\hline Cleaning common areas & Joint payments in the community of owners & Monthly \\
\hline Waste & $\begin{array}{l}\text { Fees for waste collection }+ \text { initial costs for } \\
\text { the container }\end{array}$ & Monthly \\
\hline Another services & Laundry, lounge, reception & Monthly \\
\hline Internet - connectivity & Internet, television, radio tax & Monthly \\
\hline $\begin{array}{l}\text { Installation and operation of } \\
\text { the security system }\end{array}$ & Video recording, sound signal, safety door & Once \\
\hline $\begin{array}{l}\text { Smart home software and } \\
\text { updates }\end{array}$ & $\begin{array}{l}\text { Smart systems for checking the consumption } \\
\text { of energy, security, entertainment }\end{array}$ & $\begin{array}{l}\text { Once }+ \text { According } \\
\text { to need }\end{array}$ \\
\hline Door lock replacement & Because of former owner and keys & Once \\
\hline $\begin{array}{lll}\begin{array}{l}\text { Change of permanent } \\
\text { residence }\end{array} & \\
\end{array}$ & The highest cost is time at offices in this part & Once \\
\hline Garden, terrace, pool & Operating maintenance costs & Monthly \\
\hline Street parking slot fee & There are special zones for residence & Yearly \\
\hline Maintenance of used surfaces & $\begin{array}{l}\text { Cleaning the apartment (different costs for } \\
\text { wooden surfaces than for normal tiles, etc.) }\end{array}$ & Monthly \\
\hline Reserve for risks & $\begin{array}{l}\text { Risk not only in housing. Risks of lifestyle, job } \\
\text { loss, breaking equipment, etc. }\end{array}$ & Monthly \\
\hline $\begin{array}{l}\text { Increased noise at the rush } \\
\text { street }\end{array}$ & Higher costs for more effective windows & Once \\
\hline $\begin{array}{l}\text { Distance of some bigger } \\
\text { grocery store }\end{array}$ & In these types may family buy cheaper things & Weekly \\
\hline $\begin{array}{l}\text { Transport and time, Public } \\
\text { transport, Car. }\end{array}$ & $\begin{array}{l}\text { Costs depend on distance to the work, } \\
\text { number and age of members in household. } \\
\text { Distance of schools or sport activities. }\end{array}$ & Monthly \\
\hline Costs of other opportunities & $\begin{array}{l}\text { Investing in business, stock markets, car, art, } \\
\text { etc. }\end{array}$ & Once \\
\hline
\end{tabular}

Some of these costs cannot be concluded and their prediction is difficult. However, it is essential to count on them in an approximate amount. Transporting to work and bringing children to school can be time-consuming, with side effects on fuel consumption, vehicle wear and loss of time on 
productive activities. These hard-to-determine costs can be the reasons for the later sale of the property and thus the loss of some invested money.

Mortgage loan can be repaid up to 30 years. This is a long time for specific predictions of the development of individual costs. However, for the first third of the loan duration, the prediction is crucial. This period may also be equal to the period of fixation of the agreed interest and check the costs before refinancing to make it clear where the buyer will move the new mortgage rate relative to household income.

The interest on the mortgage is deductible from the tax base, which brings a certain advantage, but slight. There is no major support for operating and related housing costs in the Czech Republic. Young families are supported by the state. However, they must meet several conditions in order to receive soft loans. Nowadays, however, low interest rates do not contribute to improving the availability of housing. However, buyers and consulting firms themselves can help financial literacy to reduce the risk of a potential crisis. Risk reduction would be done by considering the cost of living of the project - the purchase of real estate. Only prudent purchases can maintain a relatively stable real estate market.

The best way to verify the availability of housing from a financial point of view is to compare household income with future expenditure. The above list of costs can serve as a basic checklist. The selected costs that will most likely be realized subsequently enter into the calculation. The result of the calculation is the total monthly cost of housing.

\section{Conclusion}

This article discusses the importance of tracking costs and applying cost management processes to real estate business. The subjects of business are mainly residential units and family houses. A comprehensive overview of all costs that may arise during the ownership of a property and must be considered has been created. The buyer must deal with these costs when planning the acquisition of the property in order to determine if the property is affordable. If the individual cost management processes are followed, it is possible to predict a lower number of unreasonable purchases. The basic processes are cost planning, estimation of cost items, budget creation and subsequent control of compliance with the plan or recalculation. This could have a positive impact on financial crisis management in the future. In different regions, the real estate market behaves in a slightly different way depending on several factors. The cost of housing may also differ, at least in the amount. On the other hand, there are also similarities that should be used to better understand the functioning of the market and the possible application of knowledge from areas already explored.

The real estate market is a very complex industry that brings together several industries together, and therefore there is a need for expert opinion for buyers who are not engaged in this industry. The real estate market combines technical, economic and legislative knowledge. Being an expert in all areas is very difficult, and therefore this article was created to bring the issue closer to as many people engaged in real estate.

\section{Acknowledgement}

This work was supported by the Grant Agency of the Czech Technical University in Prague; grant called "The assessment methodology for supplier selection in terms of building information modeling". 


\section{References}

[1] Guarini, M., Battisti, F. a Chiovitti, A..(2018) A Methodology for the Selection of Multi-Criteria Decision Analysis Methods in Real Estate and Land Management Processes. Sustainability. vol. 10. 2018, 10(2). DOI: 10.3390/su10020507. ISSN 2071-1050. Available at: http://www.mdpi.com/2071-1050/10/2/507

[2] Maksimović, G., Jović, S., Jovović, D. a Jovović, M.. (2019) Analyses of economic development based on different factors. Computational Economics. vol. 53. 2019, 53(3), 1103-1109. DOI: 10.1007/s10614017-9786-1. ISSN 0927-7099. Available at: http://link.springer.com/10.1007/s10614-017-9786-1

[3] Geipele, I. a Kauškale, L.. (2013) The Influence of Real Estate Market Cycle on the Development in Latvia. Procedia Engineering. vol. 57. 2013, 57, 327-333. DOI: 10.1016/j.proeng.2013.04.044. ISSN 18777058. Available at: https://linkinghub.elsevier.com/retrieve/pii/S1877705813007777

[4] Project Management Institute: A guide to the project management body of knowledge (PMBOK guide), (2013). Fifth edition. Newtown Square, Pennsylvania: Project Management Institute. ISBN 978-1935589-67-9.

[5] Sreality.cz-reality a nemovitosti z celé ČR. (2020). Available online at: https://www.sreality.cz/ (accessed 4 Apr 2020)

[6] Sreality.cz-reality a nemovitosti z celé ČR. (2020). Available online at: https://www.sreality.cz/detail/prodej/byt/2+kk/praha-miskovicebendlova/661335644\#img=0\&fullscreen=false/ (accessed 16 Apr 2020)

[7] Fincentrum Hypoindex: Hypoindex.cz (2008). Prague. Available at: https://www.hypoindex.cz/ (accessed 16 Apr 2020) 